Maurer School of Law: Indiana University

Digital Repository @ Maurer Law

1984

\title{
Reinterpreting the Religion Clauses: Constitutional Construction and Conceptions of the Self
}

Susan H. Williams

Indiana University Maurer School of Law, shwillia@indiana.edu

Follow this and additional works at: https://www.repository.law.indiana.edu/facpub

Part of the Constitutional Law Commons, First Amendment Commons, and the Religion Law

Commons

\section{Recommended Citation}

Williams, Susan H., "Reinterpreting the Religion Clauses: Constitutional Construction and Conceptions of the Self" (1984). Articles by Maurer Faculty. 920.

https://www.repository.law.indiana.edu/facpub/920

This Article is brought to you for free and open access by the Faculty Scholarship at Digital Repository @ Maurer Law. It has been accepted for inclusion in Articles by Maurer Faculty by an authorized administrator of Digital Repository @ Maurer Law. For more information, please contactrvaughan@indiana.edu. 


\section{REINTERPRETING THE RELIGION CLAUSES: CONSTITUTIONAL CONSTRUCTION AND CONCEPTIONS OF THE SELF}

The first amendment guarantees freedom from "law[s] respecting an establishment of religion or prohibiting the free exercise thereof." 1 The apparent tension between the two clauses of this provision ${ }^{2}$ has generated judicial confusion ${ }^{3}$ and scholarly disagreement. ${ }^{4}$ The perceived conflict between the religion clauses is the product of a particular understanding of what is most fundamental about human identity and the human situation - an understanding that derives from classical liberal political theory and that assumes a sharp division between the individual and his community. This Note proposes an alternative to the liberal conception of human identity, one that encompasses both the separateness of the self and its connection to others. This understanding of the self can reveal a unified purpose underlying the clauses and can explain the lingering tension within them as a manifestation of their joint effort to maintain equilibrium between the two aspects of the self. Analyzing this conception's implications not only betrays the inadequacies of present theories and suggests a more coherent interpretation of the existing doctrine; it also demonstrates that constitutional construction rests on choices among various conceptions of the self and of the relationship between the self and society.

\section{Prevailing Theories and the Liberal Conception of the SELF}

\section{A. Three Prevailing Theories}

Jurists have advanced three types of theories in response to the conflict between the religion clauses. Each type is defined by its emphasis on one of the three values traditionally associated with the religion clauses: institutional separation, personal voluntarism, and

1 U.S. Const. amend. I. The Supreme Court has held that the religion clauses apply not only to the federal government, but also to the states through the fourteenth amendment. See Everson v. Board of Educ., 330 U.S. I, 15 (1947) (the establishment clause); Cantwell v. Connecticut, 310 U.S. 296, 303 (1940) (the free exercise clause).

2 The Court has acknowledged the conflict between the religion clauses. See Walz v. Tax Comm'n, 397 U.S. 664, 668-69 (1970) ("The Court has struggled to find a neutral course between the two Religion Clauses, both of which are cast in absolute terms, and either of which, if expanded to a logical extreme, would tend to clash with the other."). Scholars have also recognized the conflict. See, e.g., Choper, The Religion Clauses of the First Amendment: Reconciling the Conflict, $4 \mathrm{I}$ U. PITT. L. REV. 673, 674 (1980); Schwarz, No Imposition of Religion: The Establishment Clause Value, 77 YALE L.J. 692, 692 (1968).

3 See, e.g., Committee for Pub. Educ. \& Religious Liberty v. Regan, 444 U.S. 646, 67 I (I980) (Stevens, J., dissenting); Lemon v. Kurtzman, 403 U.S. 602, 612 (1971).

${ }^{4}$ See infra pp. $1469-70$. 
governmental neutrality. Each theory is incomplete - each focuses on only one value because it cannot accommodate the other, apparently irreconcilable, values protected by the clauses. Paradoxically, however, this perceived irreconcilability stems from a conception of human identity shared by all three theories.

Separationist theorists 5 interpret the establishment clause to require a wall of separation between church and state. ${ }^{6}$ This barrier protects the "garden of the church" from the encroaching "wilderness of the world" 7 and insulates the political process from the jealousy and divisiveness caused by religious strife. ${ }^{8}$ But complete separation is impossible in an interdependent society; government and religious organizations continually act in ways that affect one another. Because we cannot eliminate this interaction, we can only choose how much and what kind of interaction there shall be. ${ }^{9}$ Another difficulty with separation is that it may require the sacrifice of neutrality and voluntarism, the values emphasized by the other theories. For example, a scheme of educational funding that provided aid to parochial schools might serve both neutrality and voluntarism. Nonetheless, the principle of strict separation would prohibit such funding. ${ }^{10}$

Voluntarist theories embody the principle that lies at the heart of most free exercise claims - the principle that a person should be free

5 For the Supreme Court's statement of the strict separation theory, see Everson v. Board of Educ., 330 U.S. I, I5-I6 (I947) (upholding constitutionality of state-funded transportation for children in parochial as well as public schools). Although the aid at issue in Everson was approved, the language of the opinion indicated that strict separation was the standard to be used in evaluating the constitutionality of government aid to religious institutions. For arguments supporting that standard, see Pfeffer, Church and State: Something Less Than Separation, I9 U. ChI. L. Rev. I (195I); Pfeffer, Federal Funds for Parochial Schools? No., 37 Notre DAME LAW. 309 (I962).

6 See Letter from Thomas Jefferson to Nehemiah Dodge and Others, A Committee of the Danbury Baptist Association (Jan. I, I802), reprinted in T. JefFerson, The Portable Thomas JeFFERSON 303, 303 (M. Peterson ed. 1975).

7 M. Howe, The Garden and the Wilderness 5-6 (1965) (quoting P. Miller, Roger Williams: His Contribution to the American Tradition 89, 98 (I953)).

8 See Committee for Pub. Educ. \& Religious Liberty v. Nyquist, 413 U.S. 756, 795-96 (1973); Lemon v. Kurtzman, 403 U.S. 602, 622-23 (1971); J. Madrson, A Memorial and Remonstrance, in The MIND OF THE FoundER 8, I4 (M. Meyers ed. 1973); Freund, Public Aid to Parochial Schools, 82 HARV. L. REV. I680, I692 (1969) ("[P]olitical division on religious lines is one of the principal evils that the first amendment sought to forestall.").

${ }^{9}$ See Giannella, Religious Liberty, Nonestablishment, and Docirinal Development: Part II. The Nonestablishment Principle, 8r HARV. L. REV. 513, 548 (1968); Laycock, Towards a Theory of the Religion Clauses: The Case of Church Labor Relations and the Right to Church Autonomy, 81 Colum. L. REV. 1373, I379 (r981).

${ }^{10}$ See, e.g., Committee for Pub. Educ. \& Religious Liberty v. Nyquist, 4 I3 U.S. 756, 76267 (1973) (noting that challenged statutes applied equally to religious and nonreligious private schools); id. at 788-89 (noting that "[the state's] program of tuition grants . . . [was] designed to promote the free exercise of religion"). 
from both constraint and compulsion in the exercise of his religion. ${ }^{11}$ The case for voluntarism is strongest when someone requests a religious exemption to a facially neutral law - for example, a school attendance law. ${ }^{12}$ The individual is not asking the government to shape its policy according to his religious beliefs; he is simply requesting an exemption from requirements that he cannot in good conscience fulfill. Such an exemption, however, threatens the separation of governmental and religious authorities by encouraging the state to investigate the content of religious beliefs in order to determine whether they warrant an exemption. Moreover, requiring the law to create explicit exemptions based on religious categories compromises the government's neutrality. ${ }^{13}$

Some theorists believe that the principle of governmental neutrality can integrate both clauses. ${ }^{14}$ Theories of neutrality call for the proscription of government actions based on religious classifications; to pass muster, distinctions that determine rights and responsibilities must be neutral with respect to religion. ${ }^{15}$ But this putative reconciliation of the clauses is illusory: neutrality is sometimes achieved at the expense of both separation and voluntarism. For example, if a church sought an exemption from a law regulating the use of alcoholic beverages, neutrality would require the state either to regulate ceremonial as well as nonceremonial uses of alcohol or to abandon the regulation of alcohol altogether. If the state chose the former course, both separation and voluntarism would suffer.

All of the prevailing theories suggest that, when the two religion clauses conflict, one of the traditional values should prevail at the expense of the others. Thus, these theories fail to comprehend both

11 Some writers contend that the free exercise clause limits the establishment clause because the essence of the free exercise claim - that the government has violated the principle of voluntarism - is a necessary part of every establishment claim. This reasoning ensures that the establishment clause can never reach further than the free exercise clause does. See, e.g., Choper, supra note 2 , at 675 (arguing that the establishment clause is violated only if the government action "is likely to impair religious freedom by coercing, compromising, or influencing religious beliefs").

12 See Wisconsin v. Yoder, 406 U.S. 205 (1972).

${ }^{13}$ For instance, in Sherbert v. Verner, 374 U.S. 398 ( $\left.\mathrm{g}_{93}\right)$, the Court required South Carolina to exempt Sabbatarians from a state statute denying unemployment compensation to persons who refused to work on Saturday. Such an exemption entangles church and state because it forces the government to determine whether a particular claimant's objection is truly a religious one. The exemption also sacrifices neutrality: "The State . . . must single out for financial assistance those whose behavior is religiously motivated, even though it denies such assistance to others whose identical behavior . . . is not religiously motivated." Id. at 422 (Harlan, J., dissenting).

14 See Giannella, Religious Liberty, Nonestablishment, and Doctrinal Development: Part I. The Religious Liberty Guarantee, 80 HARv. L. REv. 1381, I382 (1967).

${ }^{15}$ See Kurland, Of Church and State and the Supreme Court, 29 U. CHI. L. REv. I, 5-6 (I96I). 
the relationship among the values and the interdependence of the clauses. This failure is rooted in the liberal conception of the self that informs all three attempts to reconcile the clauses.

\section{$B$. The Liberal Conception of the Self}

The prevailing approaches to the religion clauses implicitly divide the world into two spheres: public and private. The private sphere is the locus of desire and belief, of irrationality and moral value, and hence of religion. The public sphere is the locus of action - of rational procedures for the attainment of defined goals. ${ }^{16}$ This dichotomy superficially explains the purposes of the religion clauses: the establishment clause keeps religion out of the public sphere, and the free exercise clause protects religion within the private sphere. ${ }^{17}$ Together the clauses guard the integrity of both realms.

The demarcation of public and private spheres can be traced to a particular understanding of the nature of the individual and his connection to society. According to this theory of the self, on which liberal political philosophy is grounded, ${ }^{18}$ an individual's identity is completely defined before he enters society. Thus, he comes to any group he may join as a fully formed self, prepared to choose the desires, beliefs, and values that will be his ends. ${ }^{19}$ The liberal state, whose legitimacy depends on the consent of its members, ${ }^{20}$ must, consequently, be rational and substantively neutral in order not to prejudice the value choices of any of its members. ${ }^{21}$ It must operate only upon the external realm of action, not upon the internal realm of belief. ${ }^{22}$ The requirements of a consent-based society, in which each individual self is completely defined before the group is formed, thus entail the division between the public and private spheres.

The image of divided spheres of human experience is what generates the conflict between the religion clauses. Each clause aims to protect the integrity of one sphere, but the two spheres inevitably

${ }^{16}$ See Frug, The City as a Legal Concept, 93 Harv. L. Rev. 1057, 1074-76 (1980).

17 See Reynolds v. United States, 98 U.S. 145, 164 (I878) (holding that the effect of the first amendment is to "deprive[ [Congress] of all legislative power over mere opinion, but [leave it] free to reach actions").

18 Michael Sandel associates liberalism with a deontological (rights-based) ethic and argues that deontology has a "transcendental subject" as its necessary foundation. See M. SANDEL, LiBERALISM AND THE Limits OF JUSTICE I-7 (I982). Deontology is a theme common to the otherwise diverse collection of theories often labeled "liberal."

19 See id. at I9, 133 .

20 See T. HobBEs, LeviathaN 228-29 (C. Macpherson ed. I968) (Ist ed. London I65I); J. Locke, The Second Treatise of Government 54 (T. Peardon ed. I952) (Ist ed. London 169o); Wolff, Beyond Tolerance, in R. Wolff, B. Moore \& H. Marcuse, A Critique of PURe TOlERANCE 3, 5 (2d ed. I969).

21 See M. SANDEL, supra note I8, at 9 (liberalism holds that "[s]ociety is best . . governed by principles that do not presuppose any particular conception of the good, for any other arrangement would fail to respect persons as beings capable of choice").

22 See J.S. MILL, ON LiberTy I4I-42 (G. Himmelfarb ed. I974) (Ist ed. London I859). 
collide. The private sphere may invade the public sphere through public practice of religion, ${ }^{23}$ proselytization, ${ }^{24}$ or requests for exemptions from generally applicable rules. ${ }^{25}$ If the public sphere acquiesced to religious demands, it would relinquish its claim to substantive neutrality: the state would be barred from processing religious and nonreligious desires in the same way and instead would be required to accommodate the special needs of religious believers explicitly. If, to the contrary, the public sphere steeled itself against religious infiltration, the private sphere would be impoverished: it would be left without the means to enforce the guarantee of religious freedom in the face of governmental intransigence. ${ }^{26}$

The separationist, voluntarist, and neutrality theories all attempt to resolve the conflict between the public and private spheres. Separationist theories sacrifice the vitality of the private sphere to the integrity of the public sphere by denying public support for religious practices. Voluntarist theories yield the opposite result. Neutrality theories, finally, propose to mediate between the two spheres by measuring state action against a formal, procedural standard. This procedural solution, however, may result in the sacrifice of the substantive values of separation and voluntarism on which the integrity of both spheres depends. ${ }^{27}$ The attempt to maintain an untenable division between two interdependent aspects of experience is the result of an individualistic, liberal conception of the self. Because the prevailing theories share this conception, none of them can resolve the conflict between the clauses without impinging upon one or both of the spheres.

\section{An Alternate Conception of the Self}

The self can be conceived in another way. It may be viewed not as a subject with predetermined boundaries, but as the fulcrum of a dynamic equilibrium between two competing yet complementary aspects of human identity: separation from and connection to other human beings. When interpreted in light of this conception, the religion clauses take on a new meaning: their purpose is to strike a balance between these two aspects of the self. The values of sepa-

${ }^{23}$ See, e.g., School Dist. v. Schempp, 374 U.S. 203 (1963) (prohibiting state-sponsored prayer in public schools).

24 See, e.g., Murdock v. Pennsylvania, 3 I9 U.S. I05 (I943) (striking down license tax as applied to distributors of religious literature).

25 See, e.g., Sherbert v. Verner, 374 U.S. 398 (1963) (holding that state must exempt Sabbatarians from requirement that recipients of unemployment compensation be available for work on Saturday).

${ }^{26}$ In Wisconsin v. Yoder, 406 U.S. 205 (1972), for example, the Court noted that expert testimony had been offered to prove that "compulsory high school attendance could ... ultimately result in the destruction of the Old Order Amish church community." Id. at 212.

27 See supra pp. $1469-70$. 
ration, neutrality, and voluntarism are the means by which that balance is maintained. The resulting social structure is characterized not by the collision of two purportedly distinct spheres, but by a social commitment to plurality and choice that fosters a network of richly interwoven communities.

The self has a dual nature. In an important sense, each individual has a separate, unique identity. ${ }^{28}$ Our perception of this separateness may be due in part to the simple biological fact that each of us is a separate organism. ${ }^{29}$ Another source of this perception is our experience of making choices. ${ }^{30}$ In the process of choosing for ourselves, creating ourselves, each of us defines the boundary between self and others and gives it psychological and moral significance. This boundary establishes the individual's separate identity.

Collective identity is another essential part of the personality. ${ }^{31}$ Human beings belong to socially and biologically defined groups families, neighborhoods, ethnic groups - that determine not just what we want, but also who we are. ${ }^{32}$ Our consciousness of these connections, our sense of belonging, constitutes collective identity. Through self-reflection, each of us participates in our connections to these communities, not by choosing or creating the connections, but by discovering and acknowledging them. ${ }^{33}$

Although the separate and collective aspects of the self are in some sense opposed, they are not hostile to one another. Rather, like the subject and background in a painting, they are mutually defining. Collective identity presupposes separate identity, in the form of the

28 The separation of self and other is a basic assumption of the classical liberal political tradition. See, e.g., J. Locke, supra note 20 , at $54-55$ (society is created through a social contraft among separate individuals). For a modern version of social contract theory, see $\mathrm{J}$. RAWLS, A THEORY OF JUSTICE (I97I).

${ }^{29}$ Cf. R. Nozick, ANajrchy, State, and Utopia 33 (I974) ("There are only individual people, different individual people, with their own individual lives.").

30 See M. SANDEL, supra note 18 , at 58-59 (discussing the relation between choice and the antecedently defined self).

31 Many philosophers have recognized the collective aspect of identity. See, e.g., G. HEGEL, Philosophy of Righr 156 (T. Knox trans. 1979) ("[I]t is only as one of [the state's] members that the individual himself has objectivity, genuine individuality, and an ethical life."); $\mathrm{K}$. MARX, Economic and Philosophical Manuscripts, in KarL MARX: Selected Writings 75, 8I-84, 90-91 (D. McLellan ed. I977) (discussing "species being" and the possibility of its destruction through alienation); J. Rousseau, The Social Contract, in The Essential RousSEAU I, 18-20, 87-89 (L. Bair trans. 1974) (the "general will" allows for both order and freedom in a commonwealth).

32 See J. Habermas, Communication and the Evolution of Society ro8-og (T. McCarthy trans. 1979); $c f$. M. SANDEL, supra note 18 , at 150 (the "constitutive conception" of community defines "not just what [members] have as fellow citizens but also what they are, not a relationship they choose . . but an attachment they discover, not merely an attribute but a constituent of their identity"); Wolff, supra note 20 , at I8 ("Put simply, the idea is that the human personality, in its development, structure, and continued functioning is dependent upon the social group of which it is a significant member.").

33 See M. SANDEL, supra note 18 , at 152-53. 
individual's consciousness of his relation to the group; for there to be a "we," there must be an "I." 34 Similarly, the foundations of separate identity - self-knowledge, self-respect, and self-expression - depend for their very existence upon the individual's membership in a cultural and linguistic community. 35 Thus, the two facets of identity are not only consistent, but are interdependent as well. ${ }^{36}$

The religion clauses protect each of the two processes that create this dual self. The first process through which identity emerges is the process of choice. Choices that determine the individual's separate identity and define his connection to other human beings are protected by the free exercise clause. In order for choice to be effective, however, background social institutions must allow for the formation of both aspects of the self. Each community must be free to create a collective identity, but no community should be so overpowering that it threatens the individual's ability to define himself in opposition to it. The establishment clause protects this second process, through which an individual's identity is formed by the influence of communities. The clause ensures the right of both religious and political communities to influence identity independently, but it protects the individual from the potentially overwhelming power of their alliance. The two religion clauses thus protect the processes by which socialization and individual choice together shape the contours of human identity.

Individuals are influenced by a wide range of constitutionally protected communities, of which religious groups are only one. ${ }^{37}$ But the special constitutional protection for religion is more than just an historical accident. Defined functionally, a religion is a system of belief that is essential to the self-definition of the believer. ${ }^{38}$ Thus, a society that failed to protect religion would foreclose the individual's choice of the most fundamental part of his identity.

When a religious conflict arises between the individual and the state, an interpretation of the religion clauses guided by a balanced conception of the self would not lead to the collision of opposing spheres. Instead, the conflict would take the form of a boundary dispute between the political and religious communities, each of which plays a role in both the "public" and "private" spheres, and each of which claims the right to influence the individual's identity. The

${ }^{34}$ See Karst, Individuality, Community, and Law, in LAW AND THE AMERICAN FUTURE 68, 74 (M. Schwartz ed. 1976).

35 See id. at 75.

${ }^{36} \mathrm{Cf}$. Kennedy, Form and Substance in Private Law Adjudication, 89 HARv. L. REv. 1685, 1713-22 (1976) (discussing the interdependence of individualism and altruism).

37 See, e.g., NAACP v. Alabama ex rel. Patterson, 357 U.S. 449 (1958) (holding that the Constitution protects freedom of association and associational privacy); Pierce v. Society of Sisters, 268 U.S. 5 IO (I925) (holding that the Constitution protects the right of parents to guide the upbringing of their children).

38 See infra pp. $1477-78$. 
settlement of such a dispute must be guided by the overriding goal of the religion clauses: the protection of both separate and collective identities.

\section{The Religion Clauses}

This interpretation of the religion clauses does not require a radical reconstruction of doctrine. The themes of voluntarism, neutrality, and separation that infuse existing doctrine are not merely unsalvageable products of classical liberalism's misconception of the self; they can be reconceived as the instruments through which choice and plurality enable the self to develop both separate and collective aspects. The free exercise clause protects the individual's choice of his identity, and the establishment clause protects the pluralistic structure of the background social institutions necessary to make that choice both possible and meaningful.

\section{A. The Free Exercise Clause}

Through their choices to connect or to separate themselves, individuals define their identities. The free exercise clause protects their choice of religious belief. For this protection to be effective, a definition of religion for free exercise purposes must emphasize religion's role in the formation of identity. The free exercise clause must also ensure that any impairment of this role is limited and justified. Thus construed, the free exercise clause serves as a safeguard against the government's invasion of the process through which the individual creates a separate or collective self.

I. The Definition of Religion. ${ }^{39}$ - Several prominent definitions of religion in the free exercise context share common characteristics that can best be understood in light of the suggested reinterpretation of the religion clauses. These definitions are all functional, ${ }^{40}$ and all characterize the function similarly. This approach to defining religion promotes the value of voluntarism by guaranteeing that the free exercise clause will protect individual choice.

In order to serve the free exercise clause's purpose of protecting the individual's choice of his identity, religion must be defined in terms of the formation of identity, not the content of belief. Contentbased definitions of religion contradict the very constitutional requirement that they were intended to clarify; whether such definitions focus

39 This definition is offered only for free exercise purposes. A different but related definition is discussed in the section on the establishment clause. See infra p. 1485.

40 See United States v. Seeger, 380 U.S. I63, I65-66 (I965); Note, Toward a Constitutional Definition of Religion, 9r HARv. L. REv. 1056, 1072-75 (1978). But see Choper, Defining "Religion" in the First Amendment, I982 U. ILL. L. REV. 579, 594-97 (rejecting a functional definition of religion). 
on particular beliefs or only on broad classes of concerns, they limit the range of choice that the clause was intended to protect. Such constraints on choice directly conflict with the value of voluntarism: "They enshrine an orthodoxy within a Constitution designed in part to protect unorthodoxy." 41 Any definition of religion should therefore be functional rather than substantive. ${ }^{42}$

Courts and scholars have consistently recognized two elements of a functional definition of religion. First, religious belief must have a normative component - it must morally oblige the individual to act in certain ways. ${ }^{43}$ Government, even when aiming to influence belief, operates by regulating action. ${ }^{44}$ Hence religious belief must govern action in order to generate the conflict with the state that raises a free exercise claim. Moreover, the belief that gives rise to the action must be a moral one. Beliefs resting "solely upon considerations of policy,

41 Note, supra note 40 , at ro74-75.

42 There is also a practical reason for a functional definition: it is unlikely that any contentbased definition could encompass all of the belief systems that people would generally concede to be religions. See id. at Io72-74. Further, the particular functional definition discussed here does not require that religious beliefs be shared by a group. Although for many people, religion does connote strong communal ties, see M. WALZER, OBLIGATIONS 5 (1970); Laycock, supra note 9 , at 1389 , the free exercise clause must protect beliefs that separate the individual as well as those that connect him; otherwise, the clause would disturb the balance between the two aspects of human identity. Yet by not requiring communal belief, the functional definition does not leave religious groups unprotected. The free exercise clause must shelter church autonomy because "[w]hen the state interferes with the autonomy of a church . . . it interferes with the very process of forming the religion as it will exist in the future." Id. at 1391 . To take this process out of the church's hands is also to take it out of the hands of the individual who has chosen to define himself as a church member. Thus, protecting the autonomy of the church is essential to the free exercise clause's larger task: protecting the individual's freedom to shape his identity.

${ }^{43}$ See Merel, The Protection of Individual Choice: A Consistent Understanding of Religion Under the First Amendment, 45 U. CHI. L. REV. 805, 831 (1978); Note, Religious Excmptions Under the Free Exercise Clause: A Model of Competing Authorities, 90 YALE L.J. 350, 363 (1980) [hereinafter cited as Note, Religious Exemptions]. One might object to the inclusion of a normative component in the definition of religion on the ground that "[a] number of beliefs - including the Greco-Oriental mystery cults, for example - offer no moral or ethical principles to guide their adherents, but few would argue that their attempt to put their believers in contact with the Ultimate is not religious." Note, supra note 40, at ro73 (footnote omitted). The existence of such amoral cults raises no difficulties for a norm-centered definition of religion for free exercise purposes. If a system of belief, which in other contexts we want to call religious, has no implications for behavior, it should never conflict with the demands of the state, which always pertain to the control of behavior. The only religious beliefs with which the free exercise clause need be concerned are those that influence action.

${ }^{44}$ Because belief and action are integrated stages in a single process of identity formation, the separation of the two undermines the entire process. When the establishment clause is at issue, the continuity between belief and action compels us to acknowledge the government's right to influence nonreligious belief. See infra p. 1484. When a free exercise claim arises, the inseparability of belief and action requires us to admit that religious action, as well as belief, may be protected from government interference. See Wisconsin v. Yoder, 406 U.S. 205, 220 (1972). 
pragmatism, or expediency" 45 are unrelated to the individual's choice of identity - the choice that the free exercise clause protects.

Second, to qualify as a religion, a system of belief must be fundamental to the believer's identity - it must have' an element of compulsion that justifies the protection it receives. ${ }^{46}$ Religion has been described as an "ultimate concern," 47 as "a unified belief system that cuts across and directs more than a single aspect of an individual's life," 48 and as "a faith, to which all else is subordinate or upon which all else is ultimately dependent." 49 These descriptions recognize that "the concerns of any individual can be ranked, and that if we probe deeply enough, we will discover the underlying concern which gives meaning and orientation to a person's whole life."50 To acquiesce in a demand that violates this underlying concern, the individual would have to compromise himself dramatically; the " $\mathrm{I}$ " that exists could not obey the state's command and remain intact. ${ }^{51}$ This core of belief defines religion for the purposes of the free exercise clause; ${ }^{52}$ as the

45 Welsh v. United States, 398 U.S. 333, 342-43 (1970) (plurality opinion of Black, J.); see Yoder, 406 U.S. at 216 . The Welsh case dealt with statutory religious exemptions from the draft. Some have argued that, if such exemptions do not include all who would qualify under the free exercise clause, they raise not only free exercise problems, but also problems under the establishment and equal protection clauses by exempting some religious beliefs and not others. See, e.g., United States v. Seeger, 380 U.S. 163 , 188 (1965) (Douglas, J., concurring); $c f$. Greenawalt, All or Nothing at All: The Defeat of Selective Conscientious Objection, I97 I SUP. CT. REv. 3r, 39 (arguing that the Seeger test has "strong constitutional overtones").

46 A different kind of compulsion, that exerted by religious authority, has also been thought to justify religious exemptions. The individual who chooses to obey such commands of conscience has not put himself beyond the reach of authority, but has only subjected himself to the dictates of another - nonpolitical - authority. See generally Note, Religious Exemptions, supra note 43 (discussing a conflict-of-laws model that recognizes the competing spheres of authority).

47 Note, supra note 40, at 1066 (quoting P. Tillich, Dynamics of Faith, I-2 (I957)). The Note offers this definition for free exercise purposes only. For the Note's definition of religion for purposes of the establishment clause, see $i d$. at 1083-89.

48 Merel, supra note 43 , at 83 I (footnote omitted).

49 United States v. Seeger, 380 U.S. 163,176 (1965).

50 Note, supra note 40 , at 1067 . This view derives from the work of Paul Tillich. See P. Tillich, supra note 47, at I-29; P. Tillich, The Protestant Era 58-59, 87-88 (1948).

51 This dilemma of the self is captured eloquently by Martin Luther's famous response at the Diet of Worms: "Here I stand, I cannot do otherwise." R. Bainton, Here I Stand: A LiFE OF MARTIN LUTHER 185 (1950) (quoting Martin Luther).

52 Cases involving powerful, insular religious communities may appear to belie this assertion: if the state does not intervene, members of such communities might well lack meaningful freedom to choose the intellectual, moral, and spiritual content of their lives. But even in such cases, nonintervention is the best way to preserve the individual's options. The background presence of the larger political community will demonstrate to the group's members that alternatives to the narrow religious community are available. If the state intervenes in order to ensure more than this minimum freedom, it may impair the religious community's ability to function. See Wisconsin v. Yoder, 406 U.S. 205, 2 I2 (I972). Only if government exercises extreme selfrestraint can the religious community remain intact; and only if both the religious community and the broader political community are allowed to flourish will the individual have the ability to choose his own identity. 
individual's belief approaches this fundamental core, ${ }^{53}$ the protection afforded by the free exercise clause approaches its fullest measure. ${ }^{54}$

2. Government Action Prohibiting the Free Exercise of Religion. - The individual's freedom to choose his identity does not, however, entitle him to override the government in every case in which a fundamental belief is at stake. If every government action that somehow affected religious practice were taken to "prohibit" free exercise within the meaning of the first amendment, the government would be crippled, incapable of fulfilling its other constitutional obligations. The boundary of permissible state action must therefore be determined by the effect such action has on the individual's choice of identity. ${ }^{\mathbf{5 5}}$

When state action deprives the individual of full membership in the political community because of his choice of a particular religious affiliation, the state interferes with free exercise. The individual's choice of identity can be protected only if the political community offers him full membership regardless of his association with a religious community. Actions that merely make it less convenient to choose a particular religious identity do not violate the free exercise clause: they do not bring the membership requirements of the two communities into conflict. But government actions that condition a legal right, privilege, or duty of citizenship upon a certain choice of religious identity do prohibit free exercise, because legal rights and duties define full membership in the political community. ${ }^{56}$

53 Although it may seem intrusive and unrealistic to require the Court to determine the importance of the belief to the believer, such a requirement is part of the standard analysis of conscientious objectors' claims. See United States v. Seeger, 380 U.S. 163, 183-84 (1965).

54 When the belief is essential to the believer's identity, the state should be required to advance a compelling interest to justify any interference with it.

55 State action explicitly motivated by the desire to limit religious freedom is clearly invalid under the establishment clause, see Epperson v. Arkansas, 393 U.S. 97, 107-09 (1968), especially if the government's policy or practice favors some religions over others, see Larson v. Valente, 456 U.S. $228,244-46$ (1982). This Section deals with the more difficult class of cases in which the government's interference serves a legitimate state purpose.

${ }^{56} C f$. Lynch v. Donnelly, 52 U.S.L.W. 4317,4322 (U.S. Mar. 5, 1984) (O'Connor, J., concurring) ("The Establishment Clause prohibits government from making adherence to a religion relevant in any way to a person's standing in the political community.").

To analyze a free exercise claim, a court must determine whether the individual, if he persists in his religious practices, will lose something that he would otherwise be entitled to. For example, in Braunfeld v. Brown, 366 U.S. 599 (196r), the Court upheld a Sunday closing law against a free exercise challenge by Jewish businessmen who suffered a financial loss because their religion required them to close on Saturday as well. The underlying issue in Braunfeld was whether the right to work at the employment of one's choice is a right in the strong sense that it is an essential feature of membership in the political community. If it is, Braunfeld was wrongly decided. But if it is not, the plaintiffs lacked a free exercise claim: if they chose to practice their religion, they would suffer only a loss of convenience and not the loss of a right or entitlement guaranteed to members of the political community. If, however, the state chose to limit unemployment compensation in a way that disqualified Sabbatarians because they would not work on Saturday, see Sherbert v. Verner, 374 U.S. $398(1963)$, they would have a valid free exercise claim because they would otherwise have a prima facie entitlement to the compensation. 
3. Compelling State Ends. - Even government actions that force the individual to choose between political and religious identities do not necessarily violate the free exercise clause. The government may justify its coercion by pointing to a compelling state end that cannot be achieved through a less restrictive means. ${ }^{57} \mathrm{~A}$ compelling end is one that is fundamental to the legitimacy of the political community in the same sense that religious belief is fundamental to the identity of the individual. The community's self-image sets the terms for its own legitimacy; it must be able to enforce fundamental requirements of membership in order to meet those terms.

Certain elements of citizenship are fundamental to most political communities; others are unique to specific political forms. Most governments base their legitimacy on the claim that they improve people's opportunities to lead productive and satisfying lives. Essential to the credibility of this claim is the government's ability to protect its citizens from violent attack. A government unable to extend this protection is unlikely to enjoy political legitimacy. ${ }^{58}$ Thus, the requirement that citizens refrain from violence toward each other serves a "compelling state end" and must be upheld against a free exercise challenge. Certain kinds of social welfare legislation - health codes, for instance - may also be indispensable to a state's claim to legitimacy. In addition, a democracy may support its legitimacy by reference to other goals - for example, political equality. A democracy that perpetuates political inequality undermines its own legitimacy; thus, restrictions on religious exercise are permissible if they are essential to maintaining political equality. ${ }^{59}$

When free exercise threatens the legitimacy of the political community, it jeopardizes the institutional structure necessary to protect the very autonomy that the individual is asserting. Thus, the state's compelling end is not an independent value to which free exercise is sacrificed; its end is, instead, the preservation of the pluralistic social structure that makes the free exercise of religion possible. The state's end, in other words, is the fulfillment of its obligations under the establishment clause.

\section{B. The Establishment Clause}

The establishment clause requires that social institutions be structured in a way that allows for the formation of both the separate and collective aspects of the self. Each of the two major themes of estab-

57 See, e.g., Reynolds v. United States, 98 U.S. 145, 164-68 (1879) (upholding Mormon's conviction for polygamy because of state's interest in preserving family and social structure).

58 Cf. M. Weber, The Theory of Social and Economic Organization i56 (A. Henderson \& T. Parsons trans. 1947) (the monopoly of force is essential to the state).

59 See Bob Jones Univ. v. United States, I03 S. Ct. 2017 (1983) (upholding federal government's refusal to subsidize racially discriminatory schools through tax exemptions). 
lishment clause theory - separation and neutrality - can be associated with a certain kind of plurality. Separation creates plurality by distinguishing political and religious communities; neutrality creates plurality by encouraging the development of diverse religious communities. Reinterpreted in light of this understanding of plurality, existing doctrine can provide the foundation for collective identity as well as the space for individual separateness.

I. Neutrality. - The Supreme Court's current establishment clause test, announced in 197 I in Lemon $v$. Kurtzman, ${ }^{60}$ crystallizes the theme of neutrality into doctrine. The first prong of the Lemon test requires that state action have a secular purpose, ${ }^{61}$ one that aims neither to advance nor to inhibit religion.62 In other words, the purpose must be neutral with respect to both particular religions and religion in general. 63

Such neutrality fosters horizontal plurality - that is, it fosters a society in which a multiplicity of communities that exert a particular kind of influence (for example, religious influence) can coexist. ${ }^{64}$ of course, neutrality cannot guarantee plurality; all the citizens of a homogeneous society might belong to the same religious group despite their government's studied neutrality. But neutrality does ensure that the comparative vitality of the competing communities to which people are exposed will depend on the popular appeal of the ideas they offer 65 and not on the government's preferences. Only the state's neutrality in this regard can protect the possibility of horizontal plurality.

Plurality supplies a basis for the formation of both collective and separate identity. Membership in a community can determine one's identity in fundamental ways even if one remains unaware of the community's influence. The collective self, however, is premised on the individual's awareness of the collective aspect of his identity. Plurality provides a contrast among communities that allows members not only to acquire distinctive group characteristics, but also to recognize that those characteristics are theirs by virtue of their membership in the group. The contrast among communities also apprises the

${ }^{60} \mathrm{See} 403$ U.S. 602, 612-13 (197I). Recent Supreme Court opinions indicate that the Court may soon abandon this test. See, e.g., Lynch v. Donnelly, 52 U.S.L.W. 4317,4320 (U.S. Mar. 5, 1984).

${ }_{61}$ See Lemon v. Kurtzman, 403 U.S. 602, 612 (1971).

62 See School Dist. v. Schempp, 374 U.S. 203, 222 (1963) (applying the standard that later became the first prong of the Lemon test).

${ }^{63}$ See Walz v. Tax Comm'n, 397 U.S. 664, 716 (1970) (Douglas, J., dissenting); Everson v. Board of Educ., 330 U.S. I, 15 (1947).

64 The social structure of the United States exemplifies such horizontal plurality. See L. Pfeffer, Creeds in Competition: A Creative Force in American Culture 82 (1958).

65 See Zorach v. Clauson, 343 U.S. 306, 313 (1952) (describing "an attitude on the part of government that shows no partiality to any one group and that lets each [religion] flourish according to the zeal of its adherents and the appeal of its dogma"); Gianella, supra note 9, at 517 . 
individual of the possibility of separating himself from any given group. Thus, horizontal plurality aids in the formation of both the collective and separate aspects of identity.

2. Separation of Church and State. - The separation of church and state - the second theme in establishment clause doctrine promotes vertical plurality. Vertical plurality refers to the simultaneous influence of several communities upon an individual whom they all claim as a member. Modern society is full of overlapping communities; an individual may belong to a family, a neighborhood, an ethnic group, a church and a nation. Two of these intersecting communities - church and state - are kept distinct by the doctrine of separation. Each of these two operates in both the public sphere (action and reason) and the private sphere (belief and emotion) of the old liberal model. Hence both communities are capable of influencing the formation of the self.

The competition of secular and sacred communities ensures balance between the separate and collective aspects of the self. Plurality prevents the overwhelming influence of a monolithic community from destroying separateness: "the historical rivalry between Church and State is ... a precious guarantee of freedom, sheltering the conscience of the individual against the dangers of a too great concentration of power." 66 Vertical plurality also provides a basis for collective identity; the contrast among groups makes us aware of the extent of our membership in each as well as the extent of our separateness. ${ }^{67}$

66 G. DE Ruggiero, The History of European Liberalism 406 (R. Collingwood trans. 1927). But see J. RousSEAU, supra note 3I, at IIO ("Anything that breaks social unity is worthless. All institutions that place man in contradiction with himself are worthless.").

67 The effect of vertical plurality on the individual's ability to separate himself from others has been obliquely recognized by those who accuse existing establishment clause doctrine of creating a "religion of secularism." See, e.g., Murray, Law or Prepossessions?, I4 LAW \& Contemp. Probs. 23, 3I (1949). The Supreme Court rejected this argument, at least in regard to prayer in the public schools. See School Dist. v. Schempp, 374 U.S. 203, 225 (1963).

Some scholars have labeled the Court's interpretation of the establishment clause "secular" because they believe that the Court's position - that "religion could not by law be made a concern of the commonwealth as such, deserving in any degree of public recognition or aid" is based upon "the essentially theological reason that religion is of its nature a personal, private, interior matter of the individual conscience." Murray, supra, at 29 (footnote omitted). Simply by refusing to establish a religion, the argument goes, the government takes a stand on a controversial point of theological dogma. See id. at 3I. As one historian has written:

[The state] is taking its stand on the assertion that the individual conscience is able by

itself to achieve a religious view of life, and can manifest its sense of the divine in all its purity only in a spontaneous and autonomous manner. It is too often forgotten, when the doctrine of the Liberal State is crystallized into a dogma, that it really consists in freedom, and that its source lies therefore in the individual.

G. DE RUGGIERo, supra note 66 , at 404-05.

To the extent that any conception of the person is fundamentally theological, these criticisms are valid but trivial. The state must operate upon some conception of the individual; the establishment clause could not reasonably be construed to prohibit a secular one. Moreover, although the government's enforcement of the separation of church and state does indeed 
Current establishment clause doctrine, as stated in Lemon v. Kurtzman, ${ }^{68}$ requires two kinds of separation. First, the state must not excessively entangle itself with religious institutions. ${ }^{69}$ Second, the state's actions must not have the primary effect of advancing or inhibiting religion. ${ }^{70}$ These two prohibitions rule out two different kinds of interaction between church and state. The first kind occurs when church and state become intertwined in managing an area in which both have a legitimate interest. Joint administration of educational or social services exemplifies such entanglement. The second kind of interaction occurs when the state - with or without the assistance of a religious institution - becomes involved in an essentially religious endeavor. Prayer in the public schools is an instance of such state-sponsored religious activity. Both kinds of interaction potentially threaten the vertical plurality that separation of church and state was designed to achieve.

In considering entanglements, courts must determine how far church and state may cooperate in pursuit of common ends. ${ }^{71}$ Judges should answer this question by examining the effect of particular entanglements on vertical plurality, the objective of separation doctrine. Vertical plurality preserves individual autonomy by maintaining a balance between two powerful institutions - a balance reminiscent of those maintained both by federalism and by the separation of powers within the federal government. ${ }^{72}$ Entanglement threatens this balance by bringing church and state into such close cooperation that they can no longer act as checks upon each other. When entanglement becomes an impediment to vertical plurality, it violates the establishment clause. ${ }^{73}$ "establish" a doctrine, the doctrine is miscast as a "theological" one: it is not fundamentally a
theory about religion, but one about individual identity. An individual's identity is defined by
his separation from the group as well as his connection to it. The separation doctrine allows
private groups to establish the communal and educational institutions necessary to the promotion
of religion as a collective enterprise, but the doctrine's protection of vertical plurality also
preserves the individual's separateness. If the denial of this separateness is part of the church's
dogma, the doctrine of separation surely conflicts with it; but there can be no neutrality on this
point.

68403 U.S. 602 (197I).

${ }^{69} \mathrm{See}$ id. at 612-13.

io See id.

71 The establishment clause permits some minimal cooperation between church and state. See Everson v. Board of Educ., 330 U.S. I, I8 (1947) ("Of course, cutting off church schools from [fire and police] services, so separate and so indisputably marked off from the religious function, would make it far more difficult for the schools to operate. But such is obviously not the purpose of the First Amendment.").

72 See School Dist. v. Schempp, 374 U.S. 203, 229 (1963) (Douglas, J., concurring).

73 Entanglement problems often arise in the context of state aid to religious educational institutions. The Supreme Court has tended to approve such aid only when administering the funds would not require extensive government supervision. Compare Lemon v. Kurtzman, 403 U.S. 602, 619 (197 I) (striking down state plan to reimburse religious schools for teachers' salaries 
Yet vertical plurality may also be impeded by a lack of cooperation between church and state. In areas of social life in which governmentsupported competition has become commonplace, religion's influence may be extinguished if no state aid is forthcoming. ${ }^{74}$ When governmental inaction would so threaten religion, "[t]he very concept of separation ... requires that the state establish conditions under which the church can act as an autonomous unit in the social order."75 Because the wall of separation should preserve two distinct sources of influence on the individual, any attempt by the state either to combine the influence of government and religion or to displace religious influence is a threat to the plurality protected by the establishment clause.

Separation is also threatened when the government advances or inhibits religion. ${ }^{76}$ The establishment clause has put certain activities beyond the power of government; the traditional wisdom has it that the distinction between action and belief marks this boundary. ${ }^{77}$ As the Supreme Court declared in West Virginia State Board of Education v. Barnette, ${ }^{78}$ "If there is any fixed star in our constitutional constellation, it is that no official, high or petty, can prescribe what shall be orthodox in politics, nationalism, religion, or other matters of opinion or force citizens to confess by word or act their faith therein."79 The holding in Barnette certainly stands for the second half of this proposition: the Court found that school children could

in part because it would require "comprehensive, discriminating, and continuing state surveillance . . . to ensure that . . the First Amendment . . . [is] respected"), with Tilton v. Richardson, 403 U.S. 672, 688 (1971) (upholding federal construction grants to sectarian universities in part because the grants involved "no continuing financial relationships or dependencies, no annual audits, and no government analysis of an institution's expenditures on secular as distinguished from religious activities"). The danger of entanglement lies in the possibility that the regulated religious institution might "capture" the state, much as regulated industries may "capture" governmental agencies assigned to oversee them. "Capture" would reduce the state's ability to exert a distinct influence and would thereby threaten vertical plurality.

74 "To withhold studiously from religious groups all benefits flowing from governmental structuring of the social order will not only result in deprivations not demanded by the purposes of nonestablishment but in some cases will actually frustrate them." Giannella, supra note 9, at 515; cf. Zorach v. Clauson, 343 U.S. 306, 313-14 (1952) (holding that the refusal to adjust school schedules to meet students' religious needs "prefer[s] those who believe in no religion over those who do believe"); Morgan, The Establishment Clause and Sectarian Schools: A Final Installment?, 1973 SUP. CT. REv. 57, 59 (observing that Catholic educators believe state aid is essential to the survival of their schools).

${ }^{75}$ Giannella, supra note 9, at 536 .

76 See Lemon v. Kurtzman, 403 U.S. 602, 612 (1971).

77 See, e.g., Cantwell v. Connecticut, 310 U.S. 296, 303-04 (1940).

${ }^{78} 319$ U.S. 624 (I943).

79 Id. at 642 . Justice Frankfurter maintained in dissent that the flag salute was conduct, see id. at 662 (Frankfurter, J., dissenting), but the salute is actually a gesture of belief whose only value to the state lies in its symbolism. A law requiring the flag salute is precisely the kind of law that the belief/action distinction, if taken seriously, would prevent. 
not be coerced into saluting the flag. ${ }^{80}$ But the first half of the proposition is a mere dictum, which the Barnette decision itself contradicts. 81

Unlike prayer in public schools, which the Court later banned as a violation of the establishment clause, the flag salute ceremony at issue in Barnette was deemed constitutional as long as those who found it unacceptable were exempted from participation. "Why? Because the prevailing, dominant view of religion classifies the flag salute as secular, in contravention of the heterodox definition devoutly held by the Witnesses." 82 Barnette thus makes clear that the wall between church and state stands not on the line between action and belief, but rather on the line between religion and politics. The state may not coerce belief, yet it may inculcate political belief through voluntary ceremonies such as the flag salute. Religious belief, on the other hand, may not be promoted by the state even through voluntary exercises. ${ }^{83}$

The theory of dual identity explains why the dividing line between church and state must trace the boundary between politics and religion, not the distinction between belief and action. If the division is to maintain the vertical plurality essential to the protection of separate identity, the political community must be free to create a civic identity ${ }^{84}$ - that is, to shape belief. Beliefs are part of the substance of identity; they are among the things that either bind us to a group or separate us from it. The wall between church and state can create vertical plurality only if both institutions are free to influence belief, and, thereby, to shape identity.

The prohibitions of state entanglement with religion and of state advancement of religion are both necessary to achieve vertical plurality. Nonentanglement alone would be insufficient to protect vertical plurality, if the respective spheres of influence of church and state were not kept separate. If the scate, with its enormous power and resources, could compete with other private communities over every element of identity, it would become a threat to vertical plurality. 85 In order both to allow the state to shape identity and to preserve a sphere for private influence, the establishment clause prohibits the

$80 \mathrm{Id}$. at 642.

81 See Schwarz, supra note 2, at 697; Shiffrin, Government Speech, 27 UCLA L. REv. 565, 567-68 (1980); Yudof, When Governments Speak: Toward a Theory of Government Expression and the First Amendment, 57 TEx. L. REv. 863, 891 (1979).

82 Freund, Public Aid to Parochial Schools, 82 HaRv. L. REv. 1680, I686 (1969).

83 See School Dist. v. Schempp, 374 U.S. $203,224-25$ (I963); Engel v. Vitale, 370 U.S. $42 \mathrm{I}, 430$ (1962).

84 See Schempp, 374 U.S. at $24 \mathrm{I}-42$ (1963) (Brennan, J., concurring); Illinois ex rel. McCollum v. Board of Educ., 333 U.S. 203, 216-17, 231 (1948) (Frankfurter, J., concurring); West Va. State Bd. of Educ. v. Barnette, 319 U.S. 624,654 (1943) (Frankfurter, J., dissenting) ("[A]n act promoting good citizenship and national allegiance is within the domain of governmental authority."); Giannella, supra note 9 , at 562 .

${ }^{85}$ See Shiffrin, supra note $8 \mathrm{I}$, at 655 . 
state from influencing religious belief. ${ }^{86}$ Although the political community may noncoercively shape a civic identity for its citizens, 87 it may not exercise its influence over all elements of identity; a sphere of influence must be reserved for religion as well.

3. The Establishment Clause Definition of Religion. - How, then, is the state to know when it has entered the forbidden realm of religion? For purposes of the establishment clause, religion should be defined by social consensus. When the government interferes with beliefs or activities generally believed to be religious, it oversteps the bounds of its constitutional authority.

This consensus-based definition is in harmony with the functional definition discussed in the free exercise context. ${ }^{88}$ Although the functional definition avoids any inquiry into the content of belief, it encompasses only those beliefs that are fundamental to the identity of the believer. ${ }^{89}$ By ensuring plurality, the consensus-based definition likewise preserves private influence over the sphere of fundamental belief. 90

Defining religion by social consensus for purposes of the establishment clause protects plurality without crippling the government. The fundamental concerns of the majority are placed beyond the influence of the state, and the minority is still protected by the free exercise clause, which provides an exemption from the law but does not invalidate it. ${ }^{91}$ Moreover, the definition guarantees that the major religious institutions that shape the consensus and provide the basis for vertical plurality will enjoy a sphere of influence free from government interference. In short, the establishment clause preserves the pluralistic social structure essential to the formation of both the separate and collective aspects of identity.

86 The belief/action distinction, although it does not mark the boundary of the state's power to influence, does define the limit of the state's power to coerce. See supra pp. 1483-84.

87 Of course, the Court has recognized that even when the individual's participation in government-sponsored exercises is completely "voluntary," some compulsion inheres in such exercises. See School Dist. v. Schempp, 374 U.S. 203, 208 n.3 (Ig63); Illinois ex rel. McCollum v. Board of Educ., 333 U.S. 203, 227 (1948) (Frankfurter, J., concurring). Thus, to the extent that the state's encouragement of public displays of belief is inherently coercive, the government may legitimately use coercive means to inculcate "political" beliefs. But it may not, as Barnette held, apply official sanctions against those who choose not to participate.

88 See supra pp. 1475-78.

89 See supra pp. $1477-78$.

90 Not all idiosyncratic beliefs - even if fundamental — will fall within the consensus-based definition of religion. This Note assumes only that any religion that falls within that definition will also fall within the free exercise definition: it will belong to the class of beliefs that are fundamental to the identity of the believer. It is in this sense that the establishment clause definition of religion is in harmony with the free exercise definition.

${ }^{91}$ See, e.g., West Va. State Bd. of Educ. v. Barnette, 319 U.S. 624 (1943). 


\section{CONCLUSION}

Any interpretation of the religion clauses of the first amendment, or indeed of the Constitution in general, rests ultimately upon a vision of the self and of society. In the past, judges have, perhaps subconsciously, based their interpretation of these clauses on the liberal conception of the individualistic self. As a result, the clauses seemed irreconcilable; they were conceived as the guardians of mutually exclusive yet inevitably conflicting realms. But the liberal conception of the self need not constrain constitutional interpretation; there is an alternate conception of the self that reaffirms the fundamental importance of community as well as that of individuality. An interpretation guided by this synthetic conception merges the two clauses into a unified guarantee of protection for both aspects of the self. The religion clauses, by mandating a social commitment to plurality and choice, protect the formation of the separate and collective aspects of identity. Government must share its influence over the individual's identity both with various other communities and with the individual himself. The political community must be willing to accept - to the limits of its legitimacy - the individual's commitment to other identities. 